\title{
Targeting multiple inhibitory receptors to reverse melanoma-induced T cell dysfunction
}

\author{
Hassane M Zarour \\ From Melanoma Bridge Meeting 2014 \\ Naples, Italy. 03-06 December 2014
}

It is now clearly established that dysfunctional/exhausted TA-specific $\mathrm{T}$ cells present in peripheral blood and at tumor sites co-express multiple inhibitory receptors. The implications of this important finding are two-fold. First, multiple subsets of TA-specific $\mathrm{T}$ cells can be identified in patients with advanced melanoma that exhibit variable levels of T cell dysfunction. Second, this observation supports the implementation of combinatorial therapies aiming at blocking multiple inhibitory pathways to enhance TA-specific immune responses and reverse tumor-induced $\mathrm{T}$ cell dysfunction. We have shown that a subset of highly dysfunctional TA-specific CD8 $+\mathrm{T}$ cells isolated from patients with advanced melanoma upregulate both PD-1 and Tim-3. PD-1 and Tim-3 blockades strongly enhance TA-specific CD8+ T cell expansion and function. Accordingly, targeting PD-1 and Tim-3 in vivo induces melanoma regression in mice. Therefore, the combination of PD-1 and Tim-3 blockade either alone or in combination with cancer vaccines appears to be a promising potent approach to reverse melanoma-induced $\mathrm{T}$ cell dysfunction and promote tumor regression in patients with advanced melanoma.

Submit your next manuscript to BioMed Central and take full advantage of:

- Convenient online submission

- Thorough peer review

- No space constraints or color figure charges

- Immediate publication on acceptance

- Inclusion in PubMed, CAS, Scopus and Google Scholar

- Research which is freely available for redistribution

Submit your manuscript at
www.biomedcentral.com/submit

( Biomed Central

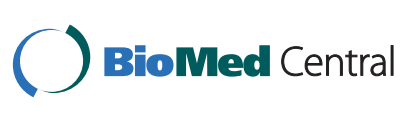

